\title{
PENGARUH BIOCHAR SERBUK KAYU DURIAN TERHADAP KARAKTERISTIK TANAH SULFAT MASAM DALAM MENGURANGI EMISI GAS METANA
}

\section{The Effect of Durian Wood Biochar on the Sulphate Soil Characteristics in Reducing Methan Gas Emission}

\author{
Evy Setiawati $^{{ }^{*}}$, Sugeng Prijono ${ }^{2}$, Diah Mardiana $^{3}$, Soemarno $^{2}$ \\ ${ }^{1}$ Balai Riset dan Standardisasi Industri Banjarbaru, Jl. Panglima Batur Barat No.2 Banjarbaru, Kalsel 70711 \\ ${ }^{2} J u r u s a n$ Tanah, Fakultas Pertanian, Universitas Brawijaya, Jl. Veteran Malang, Jatim 65145 \\ 3Jurusan Kimia, Fakultas MIPA, Universitas Brawijaya, Jl. Veteran Malang, Jatim 65145 \\ *Penulis korespondensi: evy.kemenperin@gmail.com
}

\begin{abstract}
Organic matter in the soil can provide nutrients to plants. The objectives of this study were to analyze soil characteristics after incubation using biochar at various doses, and to calculate the reduction of methane gas emissions from incubated soils. The treatments were (1) soil control (T0); (2) $4 \mathrm{t} \mathrm{ha}^{-1}$ biochar + soil (T1); (3) $8 \mathrm{t} \mathrm{ha}^{-1}$ biochar + soil (T2); (4) $12 \mathrm{t} \mathrm{ha}^{-1}$ biochar + soil (T3); (5) $16 \mathrm{t} \mathrm{ha}^{-1}$ biochar + soil (T4); (6) $20 \mathrm{t} \mathrm{ha}^{-1}$ biochar + soil (T5). The soil of each treatment was incubated for 30, 60, and 90 days. Observations were made on $\mathrm{pH}$, exchangeable cations $(\mathrm{Ca}, \mathrm{Mg}$, $\mathrm{K}, \mathrm{Na}$ ) and cation exchange capacity (CEC). Methane gas emissions were measured at 30,60, and 90 days after planting. The percentage increase in incubation soil $\mathrm{pH}$ for 30 days was $3.13-48.71 \%$, 60 days was $3.06-21.26 \%$, and 90 days was $0.41-28.26 \%$. CEC also increased from 28.83 to 37.46 me $100 \mathrm{~g}^{-1}(29.95 \%)$ at 30 days, 27.63-36.16 me $100 \mathrm{~g}^{-1}(30.86 \%)$ at 60 days, and 26.07-35.01 me $100 \mathrm{~g}^{-1}(34.28 \%)$ at 90 days. Exchangeable $\mathrm{Ca}$, and $\mathrm{Mg}$ was not significantly different for all biochar doses and incubation times. The reduction in methane gas emissions ranged from $9.57-18.08 \%$ (30 days); 33.13-35.23\% (60 days); and 46.08-73.25\% (90 days).
\end{abstract}

Keywords: acid sulphate soil, biochar, incubation, methane gas

\section{Pendahuluan}

Tanah sulfat masam yang tersebar di pulau Sumatera, Irian Jaya dan Kalimantan diperkirakan sebesar 6,71 juta ha (Balittra, 2011). Kabupaten Barito Kuala merupakan salah satu kabupaten yang mempunyai tanah rawa pasang surmemiliki lahan sulfat masam terluas di Kalimantan Selatan. Tingginya sifat masam tanah tersebut menyebabkan usaha pertanian kurang berkembang. Total luas lahan pertanian sulfat masam bekisar 120,5 ribu ha dan hanya 95,8 ribu ha yang dapat dimanfaatkan sebagai areal pertanaman padi pada tahun 2008 (Hendayana, 2010) dengan produktivitas rendah, yaitu sekitar 3 - $4 \mathrm{t} \mathrm{ha} \mathrm{h}^{-1}$ (BPS Provinsi Kalimantan Selatan, 2010). Karakteritik lahan sulfat masam mengakibatkan produktivitas tanaman padi $3,25 \mathrm{t} \mathrm{ha}^{-1}$ rata-rata dibawah lahan irigasi yaitu sebesar $4,08 \mathrm{t} \mathrm{ha}^{-1}$ (Irianto, 2012).

Faktor pembatas tingkat produktivitas padi di lahan sulfat masam adalah kelarutan $\mathrm{Fe}$, $\mathrm{Mn}$ dan $\mathrm{Al}$ yang tinggi, $\mathrm{pH}$ dan unsur hara yang rendah (Sudiakarta, 2005; Kurniawan, 2006). Pemberian biochar mampu memperbaiki $\mathrm{pH}$ dan unsur hara tanah. Aplikasi biochar pada tanah mempu menambah $\mathrm{pH}$ dari 3,5 menjadi 6,0 dan hasil tanaman hingga 2 sampai 3 kali 


\section{Jurnal Tanah dan Sumberdaya Lahan Vol 6 No 2 : 1251-1260, 2019 e-ISSN:2549-9793, doi: 10.21776/ub.jts1.2019.006.2.6}

lebih besar (Pari, 2014). Larutan tanah mengandung konsentrasi rendah dari berbagai kation, anion dan molekul organik (Brady and Weil, 2008). Komposisi larutan tanah dapat berubah terus menerus, tergantung pada suhu, serapan hara tanaman, pembasahan, pengeringan dan mineralisasi bahan organik (Vastola, 2015), oleh karena itu seringkali komposisi tanah dianggap sebagai indikator bioavailabilitas nutrisi yang baik.

Komposisi larutan tanah dapat berubah secara substansial selama penyimpananinkubasi tanah. Secara umum, kekuatan ion dari larutan tanah meningkat selama penyimpanan atau inkubasi tanah yang diairi (Mellis et al., 2017). Sayangnya, pemahaman yang baik tentang pengendalian faktor-faktor yang menyebabkan perubahan konsentrasi selama inkubasi tanah belum tercapai. Konsentrasi kation utama $(\mathrm{Ca}, \mathrm{Mg}, \mathrm{K}$, dan $\mathrm{Na}$ ) diyakini ditentukan mayoritas oleh kesetimbangan pertukaran kation ( $\mathrm{Pal}$ et al., 1983). Pemberian bahan organik untuk meningkatkan $\mathrm{pH}$ tanah masam merupakan praktik pertanian yang sangat berpotensi untuk mengubah komposisi kation yang dapat ditukar (Holland et al., 2018). Oleh karena itu apabila tanah diberi bahan organik pada berbagai dosis, akan ada peluang untuk memeriksa hubungan antara larutan tanah dan kation yang dapat dipertukarkan.

Inkubasi bertujuan agar tanah dan bahan organik mampu berinteraksi dengan baik sehingga mampu memperbaiki karakteristik fisika tanah, dan ketersediaan unsur hara dalam tanah (Asai et al., 2009; Herath et al., 2013; Siregar et al., 2017). Ketika bahan organik ditambahkan ke tanah, unsur hara tanah tidak mampu meningkat secara cepat. Inkubasi tanah selama 21 sampai 42 hari menggunakan bahan organik merupakan waktu yang tepat untuk pelepasan unsur hara ke dalam tanah agak masam. Sebelum periode inkubasi tersebut, status hara tanah mungkin belum cukup untuk mendorong pertumbuhan tanaman (Molindo, 2008). Jien dan Wang (2013) melaporkan bahwa aplikasi biochar kayu 2,5\% selama 105 hari inkubasi dapat meningkatkan KTK tanah masam. Retensi nutrisi tanah oleh biochar dapat dilakukan melalui dua mekanisme yang dimungkinkan, yaitu adsorpsi dan immobilisasi mikroba (Foereid, 2015). Bahan organik umumnya memiliki beberapa kapasitas adsorpsi sehingga mampu meningkatkan kapasitas adsorpsi tanah. Adanya sifat pori secara alamiah dan tingginya luas permukaan pada biochar dapat meningkatkan kapasitas pertukaran ion dalam tanah. Selama ini masih dianggap sangat sedikit informasi tentang lama inkubasi yang tepat untuk aplikasi biochar ke tanah (Molindo, 2008).

Tujuan dari penelitian ini adalah (i) menganalisis karakteristik tanah setelah inkubasi menggunakan biochar pada berbagai dosis dan (ii) menghitung penurunan emisi gas metana dari tanah yang ditanami padi dan diperlakukan dengan biochar.

\section{Bahan dan Metode}

Penelitian ini dilaksanakan pada bulan September 2017 sampai Juli 2018 di rumah kaca Balai Penelitian Pertanian Lahan Rawa (BALITTRA) Banjarbaru pada suhu ruangan berkisar antara 25,5 dan $37,5^{\circ} \mathrm{C}$ dan kelembaban relatif $50-80 \%$. Tanah sulfat masam berasal dari Stasiun Percobaan Belandean, Kabupaten Barito Kuala, Kalimantan Selatan pada kedalaman 0-20 cm dan dikeringkan di udara.

Dalam setiap perlakuan, tanah kering udara ditimbang $9 \mathrm{~kg}$ dan dimasukkan ke dalam pot kemudian disimpan dalam kondisi tergenang air setinggi $2 \mathrm{~cm}$ dari permukaan tanah. Tanah lapisan kedalaman $0-20 \mathrm{~cm}$ memiliki karakteristik sebagai berikut: $\mathrm{pH}$ $\left(\mathrm{H}_{2} \mathrm{O}\right) 3$,68; kation yang dapat dipertukarkan: $\mathrm{Ca}, \mathrm{Mg}, \mathrm{K}, \mathrm{Na}$ berturut turut sebesar 0,18 , 0,78, 0,12, dan 0,61 me $100 \mathrm{~g}^{-1}$; dan Kapasitas Tukar Kation (KTK) 27,88 me $100 \mathrm{~g}^{-1}$. Karakteristik biochar kayu durian yang digunakan dalam penelitian ini meliputi $\mathrm{pH}$ 8,66; kadar abu 14,75\%; zat terbang 23,30\%; Cterikat 53,20\%, carbon (C) 59,57\%; hidrogen (H) $3,09 \%$; nitrogen $(\mathrm{N}) \quad 0,49 \%$; oxygen $(\mathrm{O})$ 21,93\%; total P $115 \mathrm{mg} 100 \mathrm{~g}^{-1}$; P tersedia 2,32 mg $100 \mathrm{~g}^{-1}$; KTK 22 me $100 \mathrm{~g}^{-1}$; kation yang dapat ditukar $\mathrm{Ca}, \mathrm{Mg}, \mathrm{K}, \mathrm{Na}$ berturut turut 8,48; 1,93; 2,18 dan 1,45 me $100 \mathrm{~g}^{-1}$. Biochar ditambahkan ke tanah ini berdasarkan pada setiap dosis perlakuan. Perlakuan penelitian adalah (1) kontrol tanah, tanpa biochar (T0); (2) $4 \mathrm{t} \mathrm{ha}^{-1}$ biochar $+\operatorname{tanah}(\mathrm{T} 1)$; (3) $8 \mathrm{t} \mathrm{ha}^{-1}$ biochar + tanah (T2); (4) $12 \mathrm{t} \mathrm{ha}^{-1}$ biochar + 


\section{Jurnal Tanah dan Sumberdaya Lahan Vol 6 No 2 : 1251-1260, 2019 \\ e-ISSN:2549-9793, doi: 10.21776/ub.jts1.2019.006.2.6}

tanah (T3); (5) $16 \mathrm{t} \mathrm{ha}^{-1}$ biochar + tanah (T4); (6) $20 \mathrm{t} \mathrm{ha}^{-1}$ biochar + tanah (T5). Tanah setiap perlakuan diinkubasi selama 30, 60, dan 90 hari. Pengamatan dilakukan terhadap parameter $\mathrm{pH}$, kation yang dapat ditukar $(\mathrm{Ca}, \mathrm{Mg}, \mathrm{K}, \mathrm{Na})$ dan KTK. Pengamatan dilakukan terhadap parameter $\mathrm{pH}$, kation yang dapat ditukar (Ca, $\mathrm{Mg}, \mathrm{K}, \mathrm{Na}$ ) dan KTK. pH- $\mathrm{H}_{2} \mathrm{O}$ diukur menggunakan $\mathrm{pH}$ meter (HI9124) dengan rasio tanah:air 1:5; kation yang dapat ditukar (Ca, $\mathrm{Mg}, \mathrm{K}, \mathrm{Na})$ dianalisis menggunakan spektrometer serapan atom (Shimadzu AA7000) dan KTK diukur menggunakan $1 \mathrm{M}$ ekstraksi $\mathrm{NH}_{4} \mathrm{OAc}$ pada $\mathrm{pH} 7,0$.

Pada saat yang bersamaan, perlakuan yang sama dengan tanah inkubasi, tanah pada pot lain ditanami bibit padi berumur dua puluh dua hari. Varietas padi yang digunakan adalah Inpara 2. Varietas padi ini dipilih karena cocok untuk penanaman di tanah masam dengan umur tanaman lebih pendek (Susilawati dan Rumanti, 2018). Setelah itu emisi gas metana diukur pada 30, 60, dan 90 hari setelah tanam (HST). Perhitungan emisi menggunakan persamaan sebagai berikut (Lantin et al., 1995):

“ $E=\frac{B m}{V m} \chi \frac{\delta C s p}{\delta t} \chi \frac{V}{A} \chi \frac{273,2}{T+273,2}$,

Keterangan: E: emisi $\mathrm{CH}_{4}\left(\mathrm{mg} \mathrm{m}^{-2}\right.$ hari-1); V: volume sungkup $\left(\mathrm{m}^{3}\right)$; A: luas dasar sungkup $\left(\mathrm{m}^{2}\right)$; T: suhu udara rata-rata dalam sungkup $\left({ }^{\circ} \mathrm{C}\right) ; \delta \mathrm{Csp} / \delta \mathrm{t}$ : Laju perubahan konsentrasi $\mathrm{CH}_{4}\left(\mathrm{mg} \mathrm{kg}^{-1}\right.$ menit $\left.{ }^{-1}\right) ; \mathrm{Bm}$ : berat molekul $\mathrm{CH}_{4}$ dalam kondisi standar; Vm: volume gas pada kondisi STP (standard temperature and pressure) yaitu 22,41 liter pada $23 \circ \mathrm{K}$.

Percobaan di rumah kaca menggunakan Rancangan Acak Lengkap dengan tiga kali ulangan. Analisis varian (ANOVA) dua arah pada tingkat kepercayaan 5\% digunakan untuk menganalisis pengaruh dosis biochar terhadap karakteristik tanah menggunakan software SPSS versi 16.0. Lebih lanjut, analisis DMRT (Duncan's Multiple Range Test) digunakan untuk menganalisis perbedaan perlakuan menggunakan software SAS versi 9.1.

\section{Hasil dan Pembahasan}

Karakteristik tanah sulfat masam yang diinkubasi selama 30, 60 dan 90 hari dengan berbagai dosis biochar disajikan pada Tabel 1 .
Secara umum tanah yang diinkubasi selama 30 , 60 dan 90 hari menunjukkan perubahan karakteristik tanah akibat aplikasi biochar dibandingkan dengan kontrol. Hasil-hasil analisis ragam menunjukkan bahwa aplikasi biochar berpengaruh $\mathrm{pH}$ tanah, KTK, kation basa-dapat ditukar (Ca, Mg, K, Na) (Tabel 2).

\section{Pengaruh biochar terhadap pH tanah}

Pada Tabel 1 disajikan pengaruh dosis biochar dan lama inkubasi terhadap $\mathrm{pH}$ tanah sulfat masam. Secara keseluruhan, berdasarkan hasil analisis ANOVA (Tabel 2), inkubasi tanah dan dosis biochar beserta interaksinya berpengaruh secara signifikan terhadap $\mathrm{pH}$ tanah sulfat masam $(p<0,05)$. Tanah sulfat masam tanpa aplikasi biochar memiliki $\mathrm{pH}$ terendah. Persentase peningkatan $\mathrm{pH}$ tanah inkubasi selama 30 hari sebesar 3,13-48,71\%, 60 hari sebesar 3,06-21,26\%, dan 90 hari 0,41-28,26\% setelah ditambah biochar serbuk kayu durian yang dipirolisis pada $550{ }^{\circ} \mathrm{C}$. Dalam penelitian ini, tidak ada perbedaan signifikan pada $\mathrm{pH}$ tanah setelah penambahan biochar $4 \mathrm{t} \mathrm{ha}^{-1}, 8 \mathrm{t}$ ha $^{-1}$ dan $12 \mathrm{t} \mathrm{ha}^{-1}$ pada inkubasi 30 hari. Di sisi lain, $\mathrm{pH}$ tanah mulai berbeda secara signifikan dengan penambahan biochar 4-20 t ha $\mathrm{a}^{-1}$ pada inkubasi 60 hari, masing-masing sebesar 3,81; 3,90; 4,05; 4,32 dan 4,49.

Seiring peningkatan periode inkubasi, $\mathrm{pH}$ tanah-biochar hampir konstan dan ini bisa disebabkan kemampuan biochar untuk menyangga tanah. Apabila dibandingkan dengan inkubasi tanah selama 30 hari, terjadi penurunan $\mathrm{pH}$ tanah pada inkubasi 60 hari, hal ini dapat dimungkinkan karena dekomposisi bahan organik biochar menghasilkan asamasam organik. Seiring dengan meningkatnya dosis biochar, $\mathrm{pH}$ tanah sulfat masam dalam penelitian ini meningkat dari 0,11-1,76 unit pada inkubasi 30 hari, $0,11-0,79$ unit pada inkubasi 60 hari dan 0,02-0,59 unit pada inkubasi 90 hari. Sejalan dengan temuan Van Zwieten et al. (2010), ketika biochar diaplikasikan dengan dosis tinggi, biochar dapat meningkatkan $\mathrm{pH}$ tanah masam sebesar 1,5 hingga 2 unit. Carter et al. (2013) juga melaporkan bahwa ada peningkatan $\mathrm{pH}$ yang signifikan dari 0,6-1,2 unit setelah penambahan biochar ke tanah asam. Peningkatan $\mathrm{pH}$ tanah asam sulfat karena aplikasi biochar dapat 
dikaitkan dengan tingginya $\mathrm{pH}$ biochar yang digunakan dalam penelitian ini $(\mathrm{pH}=8,66)$, yang menyebabkan pertukaran proton cepat $\left(\mathrm{H}^{+}\right)$antara tanah dan biochar (Dume et al., 2017).

Biochar kayu yang dipirolisis secara perlahan-lahan bisa membuat alkali tanah yang diamandemen (Ajayi and Horn, 2016). pH tanah sulfat masam meningkat seiring dengan penambahan dosis biochar, hal ini dapat dikarenakan oleh adanya gugus aktif anion organik dan karbonat (-O- dan -COO-) dalam biochar, yang berkontribusi pada alkalinitas biochar (Yuan et al., 2011). Permukaan biochar mempunyai muatan negatif yang berasal dari gugus phenol, karboksil dan hidroksil yang dapat mengikat ion $\mathrm{H}^{+}$pada larutan tanah. Gugus aktif dalam biochar ini mengikat ion $\mathrm{H}^{+}$bebas dalam larutan tanah, menyebabkan konsentrasi $\left(\mathrm{H}^{+}\right)$dalam larutan tanah berkurang, sehingga dapatmeningkatkan pH tanah (Gul et al., 2015). Hasil-hasil penelitian lainnya membuktikan adanya interaksi antara karakteristik kesuburan tanah, $\mathrm{pH}$ tanah dengan aplikasi amandemen biochar pada berbagai kondisi tanah (Novak et al., 2009; Joseph et al., 2010; Laird et al., 2010; Luo et al., 2011; Nelson et al., 2011; Peng et al., 2011; Liu dan Zhang, 2012; Schulz et al., 2013; Chintala et al., 2014; Rees et al., 2014).

\section{Pengaruh biochar terhadap kation yang dapat ditukar}

Pada Tabel 1 disajikan pengaruh dosis biochar dan lama inkubasi terhadap kation yang dapat ditukar. Inkubasi tanah dan dosis biochar beserta interaksinya tidak berpengaruh secara nyata terhadap $\mathrm{Ca}$ dan $\mathrm{Mg}$, namun berpengaruh secara nyata terhadap $\mathrm{K}$ dan $\mathrm{Na}$ (Tabel 2). Persentase peningkatan terbesar untuk kation yang dapat dipertukarkan: $\mathrm{Ca}$ sebesar 41,28-210,47\% (inkubasi 90 hari); $\mathrm{Mg}$ sebesar 1,54-5,39\% (inkubasi 30 hari); K sebesar 24,35-190,43\% (inkubasi 60 hari); dan Na sebesar 13,95-40,23\% (inkubasi 30 hari).

Tabel 1. Pengaruh biochar terhadap karakteristik tanah sulfat masam yang diinkubasi selama 90 hari.

\begin{tabular}{|c|c|c|c|c|c|c|c|c|}
\hline \multirow{2}{*}{$\begin{array}{l}\text { Periode } \\
\text { Inkubasi }\end{array}$} & \multirow{2}{*}{\multicolumn{2}{|c|}{$\begin{array}{c}\text { Dosis biochar } \\
\left(\mathrm{t} \mathrm{ha}^{-1}\right)\end{array}$}} & \multirow{2}{*}{$\begin{array}{c}\mathrm{pH} \\
\mathrm{H}_{2} \mathrm{O}\end{array}$} & \multicolumn{4}{|c|}{ Kation yang dapat ditukar (me $\left.100 \mathrm{~g}^{-1}\right)$} & \multirow{2}{*}{ 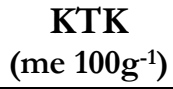 } \\
\hline & & & & $\mathrm{Ca}$ & $\mathrm{Mg}$ & $\mathbf{K}$ & $\mathrm{Na}$ & \\
\hline \multirow[t]{6}{*}{30 hari } & T0 & 0 & $3,62 \mathrm{~b}$ & $5,09 \mathrm{a}$ & $0,68 \mathrm{a}$ & $0,16 \mathrm{a}$ & $0,43 \mathrm{~b}$ & $28,83 \mathrm{c}$ \\
\hline & T1 & 4 & $3,73 \mathrm{~b}$ & $5,18 \mathrm{a}$ & $0,72 \mathrm{a}$ & $0,17 \mathrm{a}$ & $0,49 \mathrm{ab}$ & $29,87 \mathrm{c}$ \\
\hline & T2 & 8 & $3,85 \mathrm{~b}$ & $5,38 \mathrm{a}$ & $0,78 \mathrm{a}$ & $0,19 \mathrm{a}$ & $0,56 \mathrm{a}$ & $32,94 \mathrm{~b}$ \\
\hline & T3 & 12 & $4,02 \mathrm{~b}$ & $5,61 \mathrm{a}$ & $0,76 \mathrm{a}$ & $0,18 \mathrm{a}$ & $0,57 \mathrm{a}$ & $35,74 \mathrm{a}$ \\
\hline & T4 & 16 & $5,33 \mathrm{a}$ & $5,70 \mathrm{a}$ & $0,81 \mathrm{a}$ & $0,22 \mathrm{a}$ & $0,56 \mathrm{a}$ & $37,46 \mathrm{a}$ \\
\hline & T5 & 20 & $5,38 \mathrm{a}$ & $6,04 \mathrm{a}$ & $0,82 \mathrm{a}$ & $0,19 \mathrm{a}$ & $0,60 \mathrm{a}$ & $35,59 \mathrm{a}$ \\
\hline \multirow{6}{*}{60 hari } & T0 & 0 & $3,70 \mathrm{c}$ & $5,25 \mathrm{a}$ & $0,75 \mathrm{a}$ & $0,23 \mathrm{c}$ & $0,45 \mathrm{~b}$ & $27,63 \mathrm{c}$ \\
\hline & T1 & 4 & $3,81 \mathrm{bc}$ & $5,44 \mathrm{a}$ & $0,81 \mathrm{a}$ & $0,29 \mathrm{c}$ & $0,54 \mathrm{ab}$ & $31,70 \mathrm{~b}$ \\
\hline & T2 & 8 & $3,90 \mathrm{bc}$ & $6,07 \mathrm{a}$ & $0,79 \mathrm{a}$ & $0,47 \mathrm{~b}$ & $0,58 \mathrm{ab}$ & $31,72 \mathrm{~b}$ \\
\hline & T3 & 12 & $4,05 \mathrm{~b}$ & $5,90 \mathrm{a}$ & $0,80 \mathrm{a}$ & $0,52 \mathrm{~b}$ & $0,63 \mathrm{a}$ & $32,70 \mathrm{~b}$ \\
\hline & T4 & 16 & $4,32 \mathrm{a}$ & $5,81 \mathrm{a}$ & $0,77 \mathrm{a}$ & $0,53 \mathrm{~b}$ & $0,60 \mathrm{a}$ & $33,65 \mathrm{~b}$ \\
\hline & T5 & 20 & $4,49 \mathrm{a}$ & $6,09 \mathrm{a}$ & $0,80 \mathrm{a}$ & $0,67 \mathrm{a}$ & $0,61 \mathrm{a}$ & $36,16 \mathrm{a}$ \\
\hline \multirow[t]{6}{*}{90 hari } & T0 & 0 & $4,02 \mathrm{c}$ & $5,35 \mathrm{~b}$ & $0,75 \mathrm{ab}$ & $0,26 \mathrm{c}$ & $0,42 \mathrm{c}$ & $26,07 \mathrm{c}$ \\
\hline & T1 & 4 & $4,04 \mathrm{c}$ & $5,74 \mathrm{ab}$ & $0,78 \mathrm{ab}$ & $0,22 \mathrm{c}$ & $0,44 \mathrm{bc}$ & $35,01 \mathrm{a}$ \\
\hline & T2 & 8 & $4,11 \mathrm{c}$ & $5,78 \mathrm{ab}$ & $0,76 \mathrm{ab}$ & $0,38 \mathrm{~b}$ & $0,43 \mathrm{bc}$ & $31,81 \mathrm{~b}$ \\
\hline & T3 & 12 & $4,34 \mathrm{~b}$ & $6,27 \mathrm{ab}$ & $0,78 \mathrm{ab}$ & $0,48 \mathrm{a}$ & $0,53 \mathrm{a}$ & $32,12 \mathrm{~b}$ \\
\hline & T4 & 16 & $4,47 \mathrm{ab}$ & $6,25 \mathrm{ab}$ & $0,61 \mathrm{~b}$ & $0,45 \mathrm{ab}$ & $0,55 \mathrm{a}$ & $32,40 \mathrm{~b}$ \\
\hline & T5 & 20 & $4,61 \mathrm{a}$ & $6,66 \mathrm{a}$ & $0,85 \mathrm{a}$ & $0,52 \mathrm{a}$ & $0,57 \mathrm{a}$ & $32,85 \mathrm{~b}$ \\
\hline
\end{tabular}

Keterangan: angka-angka diikuti oleh huruf yang sama dalam suatu kolom berarti tidak berbeda nyata berdasarkan DMRT $\alpha=5 \%$. 
Tabel 2. Analisis ragam pengaruh dosis biochar, lama inkubasi, dan interaksinya terhadap karakteristktanah sulfat masam.

\begin{tabular}{|c|c|c|c|c|c|}
\hline Sumber ragam & $\begin{array}{l}\text { Jumlah } \\
\text { Kuadrat }\end{array}$ & $\mathrm{db}$ & $\begin{array}{c}\text { Kuatdrat } \\
\text { tengah }\end{array}$ & F-value & Signifikansi \\
\hline \multicolumn{6}{|l|}{$\mathrm{pH}$ tanah } \\
\hline Model Terkoreksi & 13.567 & 17 & .798 & 12.741 & .000 \\
\hline Intercep & 946.940 & 1 & 946.940 & $1.512 \mathrm{E} 4$ & .000 \\
\hline Inkubasi & 1.254 & 2 & .627 & 10.009 & .000 \\
\hline Dosis & 9.067 & 5 & 1.813 & 28.952 & .000 \\
\hline Interaksi Inkubasi * Dosis & 3.245 & 10 & .325 & 5.182 & .000 \\
\hline \multicolumn{6}{|l|}{ KTK tanah } \\
\hline Model Terkoreksi & 458.631 & 17 & 26.978 & 19.468 & .000 \\
\hline Intercep & 56956.928 & 1 & 56956.928 & $4.110 \mathrm{E} 4$ & .000 \\
\hline Inkubasi & 26.658 & 2 & 13.329 & 9.618 & .000 \\
\hline Dosis & 320.940 & 5 & 64.188 & 46.318 & .000 \\
\hline Interaksi Inkubasi * Dosis & 111.033 & 10 & 11.103 & 8.012 & .000 \\
\hline \multicolumn{6}{|l|}{ Ca-tukar } \\
\hline Model Terkoreksi & 9.310 & 17 & .548 & 1.428 & 181 \\
\hline Intercep & 1789.172 & 1 & 1789.172 & 4.664E3 & .000 \\
\hline Inkubasi & 2.311 & 2 & 1.155 & 3.012 & .062 \\
\hline Dosis & 6.145 & 5 & 1.229 & 3.204 & .017 \\
\hline Interaksi Inkubasi * Dosis & .854 & 10 & .085 & .223 & .992 \\
\hline \multicolumn{6}{|l|}{ Mg-tukar } \\
\hline Model Terkoreksi & .152 & 17 & .009 & 1.219 & 299 \\
\hline Intercep & 31.832 & 1 & 31.832 & $4.335 \mathrm{E} 3$ & .000 \\
\hline Inkubasi & .011 & 2 & .006 & .773 & .469 \\
\hline Dosis & .055 & 5 & .011 & 1.510 & .211 \\
\hline Interaksi Inkubasi * Dosis & .085 & 10 & .009 & 1.164 & .346 \\
\hline \multicolumn{6}{|l|}{ K-tukar } \\
\hline Model terkoreksi & 1.316 & 17 & .077 & 33.929 & .000 \\
\hline Intercep & 6.222 & 1 & 6.222 & 2.727E3 & .000 \\
\hline Inkubasi & .684 & 2 & .342 & 149.910 & .000 \\
\hline Dosis & .443 & 5 & .089 & 38.826 & .000 \\
\hline Interaksi Inkubasi * Dosis & .189 & 10 & .019 & 8.285 & .000 \\
\hline \multicolumn{6}{|l|}{ Na-tukar } \\
\hline Model terkoreksi & .240 & 17 & .014 & 3.522 & .001 \\
\hline Intersep & 15.232 & 1 & 15.232 & 3.798E3 & .000 \\
\hline Lama Inkubasi & .052 & 2 & .026 & 6.442 & .004 \\
\hline Dosis Biochar & 167 & 5 & .033 & 8.321 & .000 \\
\hline Interaksi Inkubasi * Dosis & .022 & 10 & .002 & .538 & .852 \\
\hline
\end{tabular}

Peningkatan basa yang dapat dipertukarkan ini mungkin disebabkan oleh adanya kadar abu dalam biochar yang membantu dalam pelepasan segera nutrisi mineral seperti Ca dan $\mathrm{K}$ (Nigussie et al., 2012). Namun Ca dan Mg yang dapat ditukar terlihat tidak berbeda nyata $(\mathrm{p}<0,05)$ untuk semua dosis biochar dan lama inkubasi. $\mathrm{K}$ yang dapat ditukar tidak menunjukkan perbedaan nyata dengan tanah kontrol, perbedaan nyata terdapat pada inkubasi 60 hari dan 90 hari, sedangkan $\mathrm{Na}$ berbeda nyata di semua waktu inkubasi. Aplikasi biochar mempengaruhi karakteristik dan kualitas tanah, termasuk ketersediaan hara dan kejenuhan basa dalam tanah (Yamato et al., 2006; Steiner et al., 2008; Laird et al., 2010; Lee et al., 2010; Peng et al., 2011; Mukherjee dan Zimmerman, 2013; Shen et al., 2016). 


\section{Pengaruh biochar terhadap KTK Tanah}

Pengaruh dosis biochar dan lama inkubasi terhadap KTK tanah sulfat masam disajikan pada Tabel 1. Inkubasi tanah dan dosis biochar beserta interaksinya berpengaruh secara nyata terhadap KTK tanah (Tabel 2). Hossain et al. (2010) melaporkan bahwa aplikasi biochar pada tanah meningkatkan KTK hingga 40\%, KTK dari penelitian ini meningkat dari 28,83-37,46 me $100 \mathrm{~g}^{-1}(29,95 \%)$ pada 30 hari, 27,63-36,16 me $100 \mathrm{~g}^{-1}(30,86 \%)$ pada 60 hari, dan 26,0735,01 me $100 \mathrm{~g}^{-1}(34,28 \%)$ pada 90 hari dibandingkan tanah kontrol. Biochar serbuk kayu durian memiliki KTK tinggi (22 me 100 $\mathrm{g}^{-1}$ ), oleh karena itu, tanah yang diamendemen dengan biochar kayu durian juga memiliki KTK tinggi. Liang et al. (2006) menyatakan bahwa luas permukaan yang tinggi dalam biochar dapat berkontribusi pada tingginya KTK di tanah yang mengandung biochar tinggi. Biochar dapat meningkatkan KTK tanah karena karakteristik yang melekat seperti bahan berpori dan organik (Novak et al., 2009) yang menyebabkan peningkatan kemampuan tanah untuk mengikat kation (Sujana, 2015). Semakin banyak bahan organik dan KTK dalam tanah, semakin besar kemampuan tanah untuk menyerap kation yang bisa dimanfaatkan untuk pertumbuhan tanaman. Gugus karboksilat pada permukaan biochar dan gugus karboksilat asam organik yang diserap oleh biochar, keduanya berkontribusi pada muatan permukaan negatif pada partikel biochar yang dapat meningkatkan KTK tanah (Liang et al., 2006). Pengaruh dosis biochar menunjukkan peningkatan yang tidak signifikan pada dosis $12-20 \mathrm{t} \mathrm{ha}^{-1}$ pada inkubasi 30 hari, 4-16 t ha-1 pada inkubasi 60 hari, dan 8-20 $\mathrm{t} \mathrm{ha}^{-1}$ pada inkubasi 90 hari. Hasil-hasil penelitian lainnya menunjukkan bahwa aplikasi amandemen biochar mempengaruhi karakteristik fisiko-kimia tanah dan dinamika hara dalam tanah (Glaser et al., 2002; Chun et al., 2004; Lehmann and Rondon, 2006; Liang et al., 2006; Asai et al., 2009; Ding et al., 2010; Joseph et al., 2010; Singh et al., 2010; Yao et al., 2012; Hale et al., 2013; DeLuca et al., 2015)

\section{Emisi gas metana}

Lahan sulfat masam menyumbang sekitar $90 \%$ dari total fluks $\mathrm{CH}_{4}$, sedangkan perairan terbuka daerah berkontribusi 10\%. Fluks ratarata $\mathrm{CH}_{4}$ dari seluruh lahan basah pada tahun 2002 adalah $202 \pm 77 \mathrm{mg} \mathrm{C}-\mathrm{CH}_{4} \mathrm{~m}^{-2}$ hari- $^{-1}$,

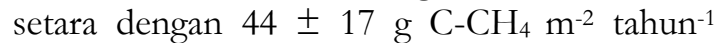
(Saquet, 2003). Emisi gas metana tanaman padi pada tanah-biochar disajikan pada Tabel 3 dan Gambar 1.

Fluks $\mathrm{CH}_{4}$ diukur pada 30, 60, dan 90 HST. Pada Gambar 13 terlihat bahwa secara umum fluks $\mathrm{CH}_{4}$ menurun seiring dengan bertambahnya dosis biochar, namun fluktuasinya meningkat seiring dengan masa tanam padi. Saat awal pertumbuhan padi, yaitu saat $30 \mathrm{HST}$, fluks $\mathrm{CH}_{4}$ harian masih rendah karena tanaman masih beradaptasi fisiologi terhadap lingkungan sekitar. Pada tahap ini masih menghasilkan C-organik yang masih rendah. Semakin lama masa tanam (umur tanaman makin meningkat), fluks metana harian juga makin bertambah. Pada saat jumlah anakan maksimal, fluks metana akan tinggi karena semakin banyak media sebagai cerobong jalur emisi (Setyanto dan Susilawati, 2007).

Pada tanah yang diamandemen biochar, penurunan emisi gas metana bekisar 9,5718,08\% (30 HST); 33,13-35,23\% (60 HST); dan 46,08-73,25\% (90 HST). Hasil-hasil penelitian ini menunjukkan emisi $\mathrm{CH}_{4}$ pada 30 hari tanam pada tanah sulfat masam yang diamandemen biochar bekisar antara 4,65-134,04 $\mathrm{mg} \mathrm{m}^{-2}$ hari-1 (30 HST); 12,1-148,62 $\mathrm{mg} \mathrm{m}^{-2}$ hari-1 $^{-1}$ (60 HST); dan 15,14-380,17 $\mathrm{mg} \mathrm{m}^{-2}$ hari $^{-1}$ (90 HST). Tanah yang diamandemen oleh biochar menghasilkan emisi lebih rendah dari amandemen bahan organik, seperti pupuk kandang, dimana amandemen tanah oleh pupuk kandang menghasilkan fluks metana harian sebesar 280,89 $\mathrm{mg} \mathrm{m}^{-2}$ hari-1 $^{-1}$ (Balingtan, 2016).

Hasil-hasil penelitian yang dilakukan oleh para peneliti lain menunjukkan bahwa aplikasi amandemen biochar ke tanah dapat menurunkan emisi gas methana (Rondon et al., 2005; Rondon et al., 2006; Spokas et al., 2009; Spokas and Reicosky, 2009; Zwieten et al., 2009; Zhang et al., 2010; Karhu et al., 2011; Liu et al., 2011; Feng et al., 2012; Zhang et al., 2012; Qin et al., 2016). 
Tabel 3. Fluks harian emisi $\mathrm{CH}_{4}$ dari tanah yang diperlakukan dengan biochar dan ditanami padi hingga umur 90 HST.

\begin{tabular}{|c|c|c|c|}
\hline Dosis & \multicolumn{3}{|c|}{$\mathrm{Emisi} \mathrm{CH}_{4}\left(\mathrm{mg} \mathrm{m}^{-1}\right.$ hari $\left.^{-1}\right)$} \\
\hline Biochar $\left(\mathrm{t} \mathrm{ha}^{-1}\right)$ & 30 HST & $60 \mathrm{HST}$ & 90 HST \\
\hline 0 & 22,73 & 47,33 & 88,39 \\
\hline 4 & 13,16 & 14,2 & 42,31 \\
\hline 8 & 15,14 & 12,26 & 22,72 \\
\hline 12 & 8,09 & 15,04 & 20,34 \\
\hline 16 & 7,53 & 16,82 & 26,59 \\
\hline 20 & 4,65 & 12,1 & 15,14 \\
\hline
\end{tabular}

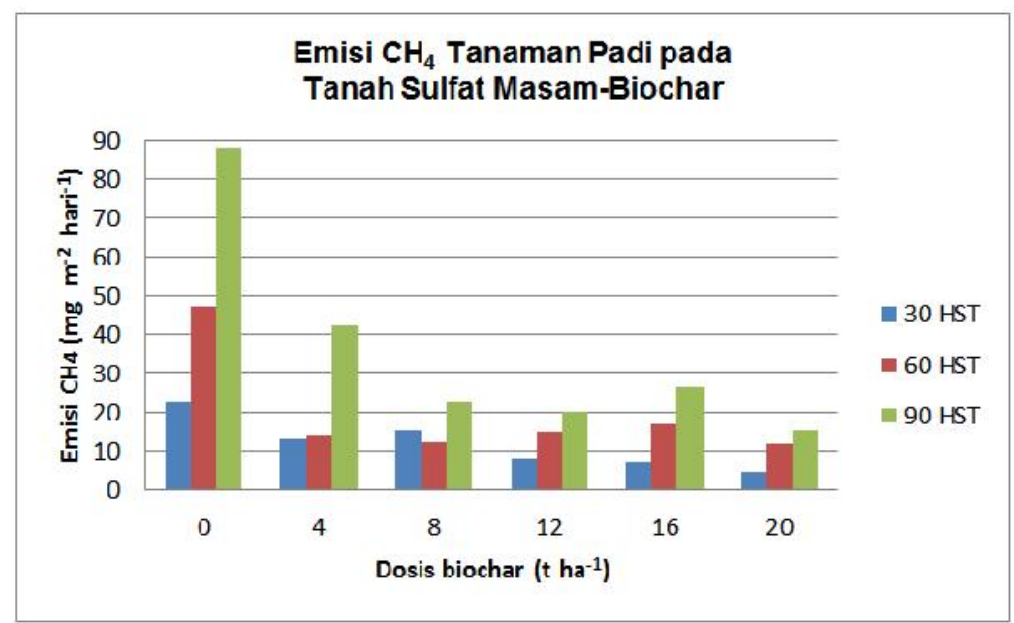

Gambar 1. Pengaruh dosis biochar terhadap emisi gas metana.

\section{Kesimpulan}

Dosis biochar serbuk kayu durian dan lama inkubasi berpengaruh positif terhadap karakteristik tanah sulfat asam. Peningkatan dosis biochar mengakibatkan peningkatan $\mathrm{pH}$ tanah dari $\mathrm{pH} 3,73$ menjadi $\mathrm{pH} 5,38$ pada inkubasi 30 hari, dari 3,81 menjadi 4,49 pada inkubasi 60 hari, dan dari 4,04 menjadi 4,61 pada inkubasi 90 hari. KTK tanah meningkat dari 29,87 menjadi 37,46 me $100 \mathrm{~g}^{-1}$ pada inkubasi 30 hari, dari 31.70 menjadi 36,16 me $100 \mathrm{~g}^{-1}$ pada inkubasi 60 hari, dan dari 31,81 menjadi 35,01 me $100 \mathrm{~g}^{-1}$ pada inkubasi 90 hari. Kandungan $\mathrm{Ca}$ dan $\mathrm{Mg}$ yang dapat ditukar tidak berbeda secara nyata untuk semua dosis biochar dan lama inkubasi, kandungan K-tukar dalam tanah berbeda secara signifikan pada inkubasi 60 hari dan 90 hari, sedangkan kandungan Na-tukar berbeda nyata di semua waktu inkubasi. Emisi gas metana yang dihasilkan dari penanaman padi di tanah yang diamandemen biochar menurun sekitar 9,57-
18,08\% (30 HST); 33,13-35,23\% (60 HST); dan 46,08-73,25\% (90 HST) dibandingkan dnegan kondisi tanpa amndemen biochar.

\section{Ucapan Terima Kasih}

Penulis mengucapkan terima kasih kepada BALITTRA Banjarbaru Kalimantan Selatan yang telah mendukung secara penuh dalam pelaksanaan penelitian ini.

\section{Daftar Pustaka}

Ajayi, A.E. and Horn, R. 2016. Modification of chemical and hydrophysical properties of two texturally differentiated soils due to varying magnitudes of added biochar. Soil \& Tillage Research(164), 34-44.

Asai,H., Samson, K.B., Stephan, M.H., Songyikhangsuthor, K., Homma, K., Kiyono, Y., Inoue, Y., Shiraiwa, T. and Horie, T. 2009. Biochar amendment techniques for upland rice production in Northern Laos 1. Soil physical 


\section{Jurnal Tanah dan Sumberdaya Lahan Vol 6 No 2 : 1251-1260, 2019 e-ISSN:2549-9793, doi: 10.21776/ub.jts1.2019.006.2.6}

properties, leaf SPAD and grain yield. Field Crops Research 111, 81-84.

Balingtan. 2016. Laporan tahun 2015 Balai Penelitian Lingkungan Pertanian. Pati.

Balittra. 2011. Potensi luas lahan dan penyebarannya, setengah abad balittra-rawa lumbung pangan menghadapi perubahan iklim. Balai Penelitian Pertanian Lahan Rawa, Balai Besar Penelitian dan Pengembangan Sumberdaya Lahan Pertanian. Badan Litbang Pertanian. Kementerian Pertanian.

BPS Prov Kalsel. 2010. Kalimantan Selatan dalam angka. Biro Pusat Statistik Provinsi Kalimantan Selatan.

Brady, N.C. and Weil, R.R. 2008. Thenature and properties of soils (14th ed.). Pearson Prentice Hall, New Jersey, USA, 990 p.

Carter, S., Shackley, S., Sohi, S., Suy, T.B. and Haefele, S. 2013. The impact of biochar application on soil properties and plant growth of pot grown lettuce (Lactuca sativa) and cabbage (Brassica chinensis). Agronomy 3; 404-418. https://doi.org/10.3390/agronomy3020404.

Chintala, R., Mollinedo, J., Schumacher, T. E., Malo, D. D. and J.L.Julson. 2014. Effect of biochar onchemical properties of acidic soil. Archives of Agronomy and Soil Science 60(3): 393-404.

Chun, Y., Sheng, G., Chiou, C. T. and Xing, B. 2004. Compositions and sorptive properties of crop residue-derived chars. Environmental Science \&Technology 38(17): 4649-4655.

DeLuca, T.H., Gundale, M.J., MacKenzie, M.D. and Jones, D.L. 2015. Biochar effects on soil nutrient transformations. Biochar For Environmental Management: Science, Technology and Implementation 2: 421-454.

Ding, Y., Liu, Y. X., Wu, W. X., Shi, D. Z., Yang, M. and Zhong, Z.K. 2010. Evaluation of biochar effects on nitrogen retention and leaching in multi-layered soil columns. Water, Air, \& Soil Pollution 213(1-4): 47-55.

Dume, B., Tessema, D., Regassa, A. and Berecha, G. 2017. Effects of biochar on phosphorus sorption and desorption in acidic and calcareous soils. Civil and Environmental Research 9(5): 10-20.

Feng,Y., Xu, Y., Yu, Y., Xie Z and Lin, X. 2012. Mechanisms of biochar decreasing methane emission from Chinese paddy soils. Soil Biology and Biochemistry 46: 80-88.

Foereid, B. 2015. Biochar in nutrient recycling-the effect and its use in wastewater treatment. Open Journal of Soil Science 5: 39-44.

Glaser, B., Lehmann, J. and Zech, W. 2002. Ameliorating physical and chemical properties of highly weathered soils in the tropics with charcoal-a review. Biology and Fertility of Soils 35(4): 219-230.

Gul, S., Whalen, J.K., Thomas, B.W., Sachdeva, V. and Deng, H. 2015. Physico-chemical properties and microbial responses in biochar-amended soils: Mechanisms and future directions. Agriculture, Ecosystems and Environment 206: 46-59.

https://doi.org/10.1016/j.agee.2015.03.015.

Hale, S.E., Alling, V., Martinsen, V., Mulder, J., Breedveld, G.D. and Cornelissen, G. 2013. The sorption and desorption of phosphate-P, ammonium- $\mathrm{N}$ and nitrate- $\mathrm{N}$ in cacao shell and corn cob biochars. Chemosphere 91(11): 16121619.

Hendayana, R. 2010. Pengkajian strategi percepatan adopsi varietas padi unggul di lokasi pasang surut dan rawa untuk meningkatkan 200\% adopter di Kalimantan Selatan dan Kalimantan Tengah. Laporan Hasil Penelitian Ristek. BBSDLP.

Herath, H.,Camps-Arbestain, M. and Hedley, M. 2013. Effect of biochar on soil physical properties in two contrasting soils: an Alfisol and an Andisol. Geoderma 209: 188-197.

Holland, J.E., Bennett, A.E., Newton, A.C., White, P.J., Mckenzie, B.M., George, T.S. and Hayes, R.C. 2018. Liming impacts on soils, crops and biodiversity in the UK: A review. Science of the Total Environment 610-611: 316-332. https://doi.org/10.1016/j.scitotenv.2017.08.020

Hossain, M.K., Strezov, V., Chan, K.Y., and Nelson, P.F. 2010. Agronomic properties of wastewater sludge biochar and bioavailability of metals in production of cherry tomato (Lycopersicon esculentum). Chemosphere 78(9): 1167-1171. https://doi.org/10.1016/ j.chemosphere.2010.01.009.

Irianto, G. 2012. Ketersediaan prasarana dan sarana mendukung kedaulatan pangan dan energi. Makalah disampaikan pada Simposium Seminar Bersama PERAGI-PERHORTI-PERIPI-HIGI Mendukung Kedaulatan Pangan dan Energi Yang Berkelanjutan. IPB International Convention Center Bogor.

Jien, S. and Wang, C. 2013. Effects of biochar on soil properties and erosion potential in a highly weathered soil. Catena 110: 225-233. https://doi.org/10.1016/j.catena.2013.06.021.

Joseph,S.D., Camps-Arbestain, M., Lin, Y., Munroe, P., Chia, C.H., Hook, J., Van Zwieten, L., Kimber,S., Cowie, A., Singh, B.P., Lehmann, J., Foidl, N., Smernik R.J. and Amonette, J.E.2010. An investigation into the reactions of biochar in soil. Soil Research 48(7): 501-515.

Karhu, K., Mattila, T., Bergström, I. and Regina, K. 2011. Biochar addition to agricultural soil 


\section{Jurnal Tanah dan Sumberdaya Lahan Vol 6 No 2 : 1251-1260, 2019 e-ISSN:2549-9793, doi: 10.21776/ub.jts1.2019.006.2.6}

increased CH4 uptake and water holding capacity-Results from a short-term pilot field study. Agriculture, Ecosystems \& Environment 140(1-2): 309-313.

Kurniawan, T.P. 2006. Efikasi cuka kayu(wood vinegar) terhadap rayap $\operatorname{tanah}($ Coptotermes curvignathus Holm) dari limbah kayu Mahoni (Swietenia macrophylla King) dan kayu Kihiyang (Albizzia procera Benth).

Laird, D., Fleming, P., Wang, B., Horton, R. and Karlen, D. 2010. Biochar impact on nutrient leaching from a Midwestern agricultural soil. Geoderma 158(3-4): 436-442

Laird, D.A., Fleming, P., Davis, D.D., Horton, R., Wang, B. and Karlen, D.L. 2010. Impact of biochar amendments on the quality of a typical Midwestern agricultural soil. Geoderma 158(34): 443-449.

Lee, J.W., Kidder, M., Evans, B.R., Paik, S., Buchanan Iii, A.C., Garten, C.T., and Brown, R.C. 2010. Characterization of biochars produced from cornstovers for soil amendment. Environmental Science \&Technology 44(20): 7970-7974.

Lehmann, J. and Rondon, M. 2006. Bio-char soil management on highly weathered soils in the humid tropics. Biological Approaches To Sustainable Soil Systems 113(517): e530.

Liang, B., Lehmann, J., Solomon, D., Kinyangi, J., Grossman, J., O'neill, B.,Skjemstad, J.O., Thies, J., Luizão, F.J., Petersen, J. and Neves, E.G. 2006. Black carbon increases cation exchange capacity in soils. Soil Science Society of America Journal 70(5): 1719-1730.

Liang, B., Lehmann, J., Solomon, D., Kinyangi, J., Grossman, J., Skjemstad, J. O. and Neves, E. G. 2006. Black carbon increases cation exchange capacity in soils. Soil Science Society of America Journal 70 : $1719-1730$. https://doi.org/10.2136/sssaj2005.0383

Liu, X.H. and Zhang, X.C. 2012. Effect of biochar on $\mathrm{pH}$ of alkaline soils in the Loess Plateau: Results from incubation experiments. International Journal of Agriculture \& Biology 14(5): 21-28.

Liu, Y., Yang, M., Wu, Y., Wang, H., Chen, Y. and Wu, W. 2011. Reducing $\mathrm{CH}_{4}$ and $\mathrm{CO}_{2}$ emissions from waterlogged paddy soil with biochar. Journal of Soils and Sediments 11(6): 930-939.

Luo, Y., Durenkamp, M., De Nobili, M., Lin, Q. and Brookes, P.C. 2011. Short term soil priming effects and the mineralisation of biochar following its incorporation to soils of different pH. Soil Biology and Biochemistry 43(11): 23042314.

Mellis, E.V., Casagrande, J.C. and Soares, M.R. 2017. Nickel adsorption and desorption in an acric oxisol as a function of $\mathrm{pH}$, ionic strength and incubation time. Ciencia e Agrotecnologia 41(1): 32-41.

Molindo, W.A. 2008. Determination of the nutrient status of as soil after incubation with organic residues for different days in Benin City, Nigeria. World Journmal of Agricultural Sciences 4(6): 731-736.

Mukherjee, A. and Zimmerman, A.R. 2013. Organic carbon and nutrient release from a range of laboratory-produced biochars and biochar-soil mixtures. Geoderma 193: 122-130.

Nelson, N.O., Agudelo, S.C., Yuan, W. and Gan, J. 2011. Nitrogen and phosphorus availability in biochar-amended soils. Soil Science 176(5): 218226.

Nigussie, A., Kissi, E., Misganaw, M. and Ambaw, G. 2012. Effect of biochar application on soil properties and nutrient uptake of lettuces (Lactuca sativa) grown in chromium polluted soils. American-Eurasian Journal of AgriculturL \& Environmental Science 12(3): 369-376.

Novak, J.M., Busscher, W. J., Laird, D.L., Ahmedna, M., Watts, D.W. and Niandou, M.A. 2009. Impact of biochar amendment on fertility of a southeastern coastal plain soil. Soil Science 174(2): 105-112.

Pal, R., Mehta, S.C. and Poonia, S.R. 1983. Predicting cation exchange equilibria in soil containing three heterovalent cations. Z. Pflanzenernaehr.Bodenk 146: 604-610.

Pari, G. 2014. Biochar technology as a go green movement in Indonesia. Journal of Wetlands Environmental Management 2(1): 84-91

Peng, X.Y. L.L., Ye, L.L., Wang, C.H., Zhou, H. and Sun, B. 2011. Temperature-and durationdependent rice straw-derived biochar: Characteristics and its effects on soil properties of an Ultisol in southern China. Soil and Tillage Research 112(2): 159-166.

Qin,X., Li, Y., Wang, H., Liu, C., Li, J., Wan, Y., Gao, Q., Fan, F. and Liao, Y. 2016. Long-term effect of biochar application on yield-scaled greenhouse gas emissions in a rice paddy cropping system: A four-year case study in south China.Science of the Total Environment 569-570: 1390-1401.

Rees, F., Simonnot, M.O. and Morel, J.L. 2014. Short?term effects of biochar on soil heavy metal mobility are controlled by intra-particle diffusion and soil $\mathrm{pH}$ increase. European Journal of Soil Science 65(1): 149-161.

Rondon, M., Ramirez, J.A. and Lehmann, J. 2005. Charcoal additions reduce net emissions of greenhouse gases to the atmosphere. Proceedings of the 3rd USDA Symposium on Greenhouse Gases and Carbon Sequestration in 


\section{Jurnal Tanah dan Sumberdaya Lahan Vol 6 No 2 : 1251-1260, 2019 e-ISSN:2549-9793, doi: 10.21776/ub.jts1.2019.006.2.6}

Agriculture and Forestry, 21-24 Maret 2005, pp. 21-24.

Rondon, M.A., Molina, D., Hurtado, M., Ramirez, J., Lehmann, J., Major, J. and Amezquita, E. 2006. Enhancing the productivity of crops and grasses while reducing greenhouse gas emissions through bio-char amendments to unfertile tropical soils. In 18th World Congress of Soil Science, pp. 9-15.

Saquet, M.A.M. 2003. Greenhouse gas flux and budget from an experimentally flooded wetland using stable isotopes and geochemistry. Univerity of Waterloo.

Schulz, H., Dunst, G. and Glaser, B. 2013. Positive effects of composted biochar on plant growth and soil fertility. Agronomy for Sustainable Development 33(4): 817-827.

Setyanto, P. dan Susilawati, H. L. 2007. Mitigasi emisi gas metan pada tanah gambut dengan varietas padi. Prosiding Seminar Pertanian Lahan Rawa "Revitalisasi kawasan PLG dan lahan rawa lainnya untuk membangun lumbung pangan nasional", pp. 293-300.

Shen, Q., Hedley, M., Camps-Arbestain, M. and Kirschbaum, M.U.F. 2016. Can biochar increase the bioavailability of phosphorus?. Journal of Soil Science and Plant Nutrition 16(2): 268-286

Singh, B.P., Hatton, B.J., Singh, B., Cowie, A.L. and Kathuria, A. 2010. Influence of biochars on nitrous oxide emission and nitrogen leaching from two contrasting soils. Journal of Environmental Quality 39(4): 1224-1235.

Siregar, P., Fauzi, dan Supriadi. 2017. Pengaruh pemberian beberapa sumber bahan organik dan masa inkubasi terhadap beberapa aspek kimia kesuburan tanah ultisol. Jurnal Agroekoteknologi FP USU 5(2): 256-264.

Spokas, K.A. and Reicosky, D.C. 2009. Impacts of sixteen different biochars on soil greenhouse gas production. Annals of Environmental Science 3: 179-xx.

Spokas, K.A., Koskinen, W.C., Baker J.M. and Reicosky, D.C. 2009. Impacts of woodchip biochar additions on greenhouse gas production and sorption/degradation of two herbicides in a Minnesota soil. Chemosphere 77(4): 574-581.

Steiner, C., Glaser, B., Geraldes Teixeira, W., Lehmann, J., Blum, W. E. and Zech, W. 2008. Nitrogen retention and plant uptake on a highly weathered central Amazonian Ferralsol amended with compost and charcoal. Journal of Plant Nutrition and Soil Science 171(6): 893899.

Sujana, I. P. 2015. The effect combination of dose biochar with dose organic matters on soil characteristics and maize plants growth on land degraded by garments liquid waste. International
Journal of Research in Agriculture and Forestry 2(8): 49-54.

Suriadikarta, D.A. 2005. Pengelolaan lahan sulfat masam untuk usaha pertanian. Jurnal Litbang Pertanian 24(1): 36-45

Susilawatia nd Rumanti, I. A. 2018. Potential and constraints of rice farming in tidal swamp land.Proceedings of 162nd, The IIER International Conference. Yokohama, Japan, 9 May 2018, pp. 46-50.

Van Zwieten, L., Kimber, S., Morris, S., Chan, K., Downie, A., Rust, J. and Cowie, A. 2010. Effects of biochar from slow pyrolysis of papermill waste on agronomic performance and soil fertility. Plant and Soil 327: 235-246. https://doi.org/10.1007/s11104-009-0050-x

Vastola, A. 2015. The sustainability of agro-food and natural resource systems in the mediterranean basin. Springer Open. London, $\mathrm{UK}$

Yamato, M., Okimori, Y., Wibowo, I. F., Anshori, S. and Ogawa, M. 2006. Effects of the application of charred bark of Acacia mangium on the yield of maize, cowpea and peanut, and soil chemical properties in South Sumatra, Indonesia. Soil Science and Plant Nutrition 52(4): 489-495.

Yao, Y., Gao, B., Zhang, M., Inyang, M. and Zimmerman, A.R. 2012. Effect of biochar amendment on sorption and leaching of nitrate, ammonium, and phosphate in a sandy soil. Chemosphere 89(11): 1467-1471.

Yuan, J., Xu, R. and Zhang, H. 2011. The forms of alkalis in the biochar produced from crop residues at different temperatures. Bioresource Technology 102(3): 3488-3497.

Zhang, A., Bian, R., Pan, G. Cui, L., Hussain, Q., Li, L., Zheng, J., Zheng, J., Zhang, X., Han, X. and Yu, X. 2012. Effects of biochar amendment on soil quality, crop yield and greenhouse gas emission in a Chinese rice paddy: A field study of 2 consecutive rice growing cycles. Field Crops Research 127: 153-160.

Zhang, A., Cui, L., Pan, G., Li, L., Hussain, Q., Zhang, X., Zheng, J. and Crowley, D. 2010. Effect of biochar amendment on yield and methane and nitrous oxide emissions from a rice paddy from Tai Lake plain, China. Agriculture, Ecosystems \&Environment139(4): 469-475.

Zwieten,V.L., Singh, B., Joseph, S., Kimber, S., Cowie, A. and Chan, Y.K. 2009. Biochar and emissions of non-CO2 greenhouse gases from soil. In: Biochar for Environmental Management Science and Technology, J. Lehmann, S. Joseph (eds.). Earthscan Press, UK. pp. 227-249. 